USGS - TEI -484

CHEMISTRY

$\frac{\text { Distribution (Series A) }}{\text { Argonne National Laboratory } \ldots \ldots \ldots \ldots \ldots \ldots \ldots \ldots \ldots \ldots \ldots \ldots \ldots \ldots \ldots \ldots \ldots \ldots \ldots \ldots \ldots}$

Atomic Energy Commission, Washington ...................... 2

Division of Raw Materials, Albuquerque .................... 1

Division of Raw Materials, Austin ....................... 1

Division of Raw Materials, Butte ........................... 1

Division of Raw Materials, Casper ......................... 1

Division of Raw Materials, Denver ......................... 1

Division of Raw Materials, Ishpeming ...................... 1

Division of Raw Materials, Phoenix ........................ 1

Division of Raw Materials, Rapid City ....................... 1

Division of Raw Materials, St. George ...................... I

Division of Raw Materials, Salt Lake City ................... 1

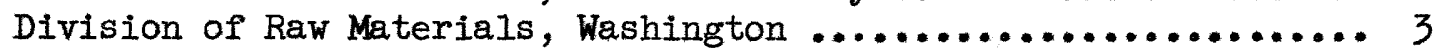

Exploration Division, Grand Junction Operations Office ........ 1

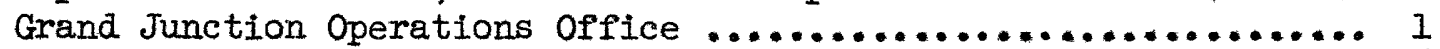

Technical Information Extension, Oak Ridge .................. 6

Tennessee Valley Authority, Wilson Dam ..................... 1

U. S. Geological Survey:

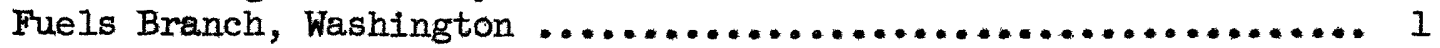

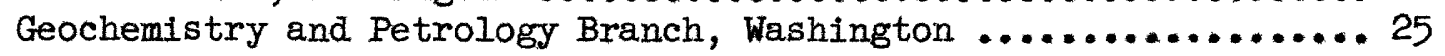

Geophysics Branch, Washington ........................... 1

Mineral Deposits Branch, Washington ...................... 1

P. C. Bateman, Menlo Park ............................... 1

A. L. Brokaw, Grand Junction ............................. 1

N. M. Denson, Denver ................................... I

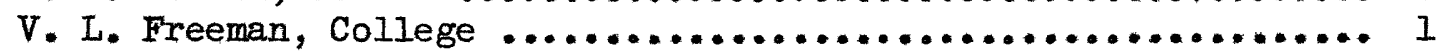

R. L. Griggs, Albuquerque ........................... 1

A. H. Koschmann, Denver ................................ 1

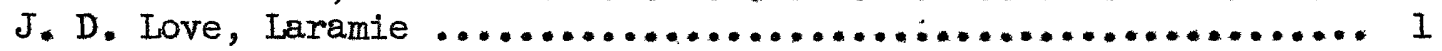

I. R. Page, Washington .............................. I

Q. D. Singewald, Beltsville .......................... 1

F. N. Ward, Denver .................................... 1

A. E. Weissenborn, spokane ............................ 1

TEPCO, Denver ........................................ 2

TEPCO, RPS, Washington, (including master) $\ldots \ldots \ldots \ldots \ldots \ldots \ldots \ldots \ldots 2$ 


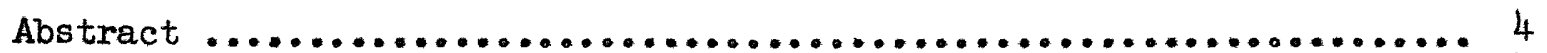

Introduction . . ............................................ 4

Physical and chemical procedures ............................... 8

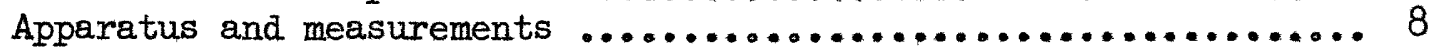

Reagents and sources ..................................... 10

Procedure for separation of nuclides ......................... II

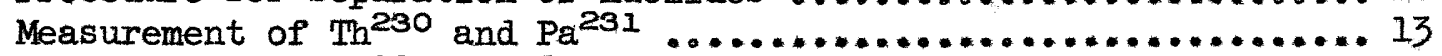

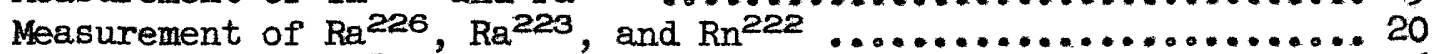

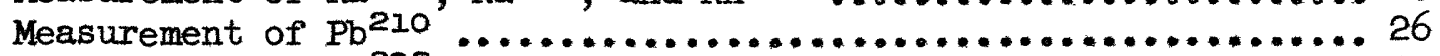

Measurement of $\mathrm{Th}^{232}$......................................... 27

Calculations ................................................. 33

Discussion .................................................. 35

Acknowledgments ............................................. 36

References ................................................. 36

\section{ILLUSTRATIONS}

Page

Figure 1. Classification of natural radioactivity in separate groups. 5

2. Decay curves for straight-line equations ............... I5

3. Plot of straight-line equations $\ldots \ldots \ldots \ldots \ldots \ldots \ldots \ldots \ldots . \ldots \ldots$

4. Build-up and decay curve of $\mathrm{Ra}^{224} \ldots \ldots \ldots \ldots \ldots \ldots \ldots \ldots . \ldots 29$

\section{TABLES}

Page

Table 1. Values used for calculation of the detection efficiencies of the 3-inch photomultiplier tubes .................... 18

2. Experimental alpha activity constants for $\mathrm{Th}^{230}$ and $\mathrm{Pa}^{231}$ determinations

3. Experimental alpha activity constants for $\mathrm{Ra}^{226}$ and $\mathrm{Ra}^{223}$ determinations

4. Experimental alpha activity constants for $\mathrm{Rn}^{222}$ determination

5. Experimental alpha activity constants for $\mathrm{Pb}^{210}$ determination

6. Experimental alpha activity constants for $\mathrm{Th}^{232}$ determination 


\title{
QUANTITATIVE RADIOCHEMICAL METHODS FOR THE DETERMINATION \\ OF THE SOURCES OF NATURAL RADIOACTIVITY, PART II
}

\author{
By John N. Rosholt, Jr.
}

\section{ABSTRACT}

The study of the state of equilibrium of any natural radioactive source requires the analysis for several key nuclides or groups of nuclides to determine their contribution to the total amount of radioactivity. The methods used for the radiochemical analysis of $\mathrm{Th}^{232}, \mathrm{Th}^{230}, \mathrm{~Pa}^{231}$, and $\mathrm{Ra}^{226}$ are described. Alpha activity measured by scintillation counting is used for the determination of these nuclides.

Standardization independent of ore standard comparison is proved necessary for the determination of $\mathrm{Rn}^{222}$ and $\mathrm{Pb}^{210}$ and the methods for determining these independently are shown. Independent and comparative values for the other nuclides are used to prove that the method of independent standardizao tion is valid.

\section{INTRODUCTION}

The usefulness of the determination of the component sources of natural radioactivity has been shown and the radiochemical methods of analysis for $\mathrm{Rn}^{222}, \mathrm{~Pb}^{210}$, and $\mathrm{Th}^{232}$ described (Rosholt, 1954). A more complete analysis of the state of equilibrium will include some additional long-lived radio. nuclides and groups of equilibrium-established short-lived daughters, namely: $\mathrm{Th}^{230}$, $\mathrm{Ra}^{226}$, and the $\mathrm{Pa}^{231}$ group in the $\mathrm{U}^{235}$ series. Thus the state of equilibrium can be rigorously defined if the contents of the following components are known: (1) uranium group, (2) $\mathrm{Th}^{230}$, (3) Ra226, (4) Rn222 group, 
U
92
$\mathrm{~Pa}$
91
$\mathrm{Th}$
90
$\mathrm{Ac}$
89
$\mathrm{Ra}$
88
$\mathrm{Fr}$
87
$\mathrm{Rn}$
86
$\mathrm{At}$
85
$\mathrm{P}$
84
$\mathrm{~B}$

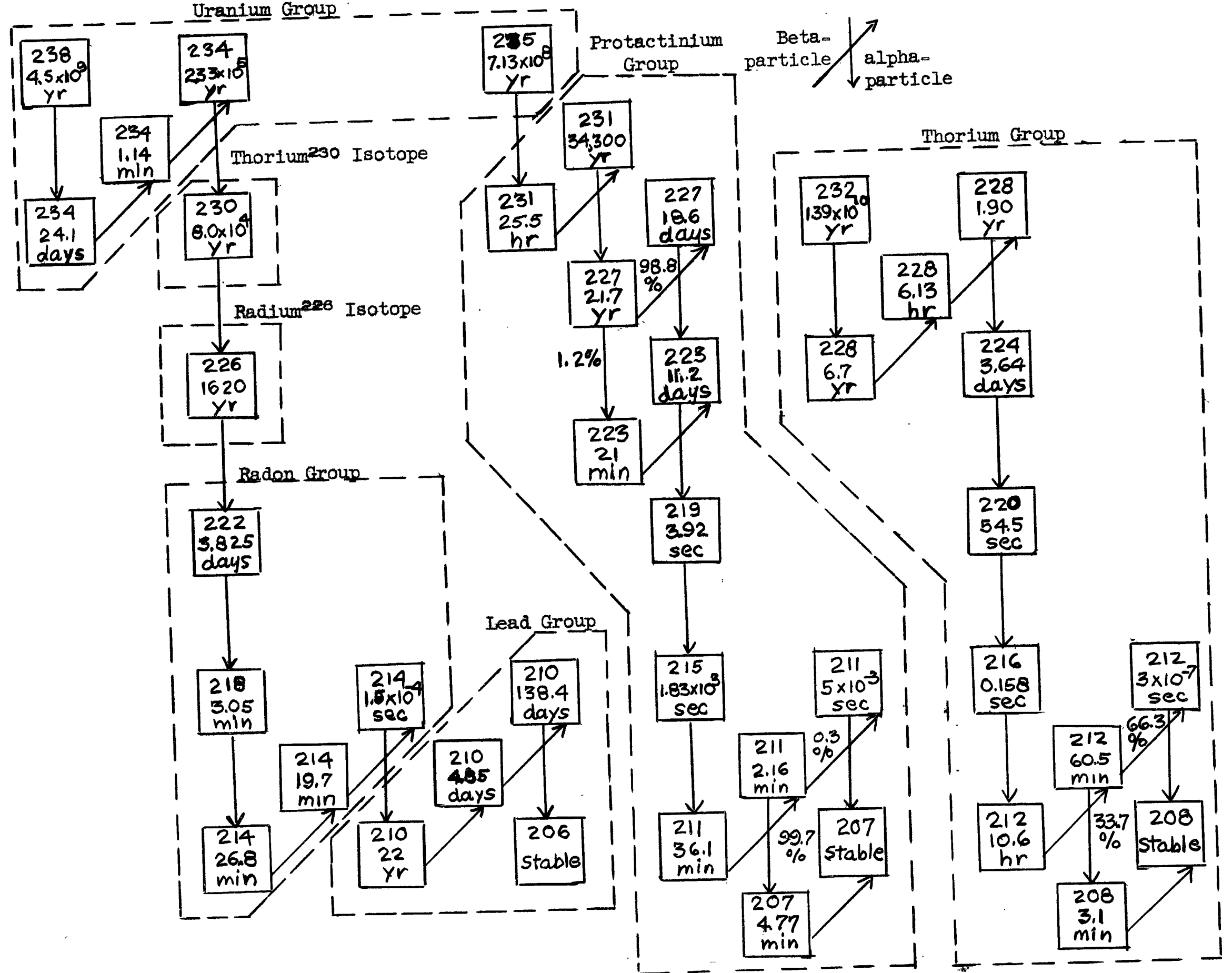

Figure 1.--Classification of natural radioactivity in separate groups. 
(5) $\mathrm{Pb}^{210}$ group, (6) $\mathrm{Pa}^{231}$ group, and (7) $\mathrm{Th}^{232}$ series. The relations of these components are shown in figure 1. Components 1 through 5 describe what can be termed the state of equilibrium. The $\mathrm{Th}^{232}$ series, though not involved in the description of equilibrium, is a major contributor of radioactivity which must be determined. Where a more rigorous definition is desired, the contribution of the state of equilibrium of the $U^{235}$ series defined by the $\mathrm{Pa}^{231}$ content must be considered.

Throughout this paper equivalent units are used. Uranium and thorium content is given as actual percent of uranium or thorium. All of the disintegration products in the three decay series are expressed as equivalents to the parent nuclides.

When equilibrium exists in a decay series, the disintegration rate of each product is identical to that of the parent. Thus the amount of pure daughter product expressed in percent equivalent will equal the amount of pure parent nuclide expressed in percent which would be required to establish equilibrium between the daughter and parent. The decay rate of this theoretically required amount of pure parent will equal the decay rate of the amount of pure daughter present.

In the case of the U235 series, the parent U $^{235}$ is expressed equivalent to $U^{238}$ by use of the abundance and half-life ratios. Any product in the $U^{235}$ series will be expressed in percent equivalent to $U^{238}$ plus $U^{235}$ which would theoretically be required for equilibrium and the activity of the U235 decay series product would be 4.5 percent of the equivalent $U^{238}$ value. For example $100 \mathrm{mg}$ of 1 percent uranium of normal isotope abundance in equilibrium with all of its decay products would contain the following amounts and activities of decay products: 
An aluminum ring, 50-mm diameter by 3-mm high with 0.005 -gauge cellophane glued to its under side, is used for the $\mathrm{ZnS}$-precipitate mount. Plastic cement is spread on the periphery of the under side of the ring directly on the cellophane, and the precipitate and membrane are mounted by adherence to this surface. A 47-mm ring without the cellophane protector is used to mount the bismuth sulfide-carried precipitate.

\section{Reagents and sources}

1. 0.014 molar $\mathrm{BI}_{2} \mathrm{O}_{3}$ in 5 percent $\mathrm{HCl}$ solution (6 mg $\mathrm{BI} / \mathrm{ml}$ ).

2. 0.014 molar $\mathrm{Pb}\left(\mathrm{NO}_{3}\right)_{2}$ solution $(3 \mathrm{mg} \mathrm{Pb} / \mathrm{ml})$.

3. 0.090 molar $\mathrm{FeCl}_{3} \cdot 6 \mathrm{H}_{2} \mathrm{O}$ solution $(5 \mathrm{mg} \mathrm{Fe} / \mathrm{ml}$ ).

4. 0.110 molar $\mathrm{ZrCl}_{4}$ solution (10 mg $\mathrm{Zr} / \mathrm{ml}$ ).

5. 0.1 molar $\mathrm{Na}_{4} \mathrm{P}_{2} \mathrm{O}_{7}$ solution.

6. $0.146 \mathrm{molar} \mathrm{BaCl}_{2} \cdot 2 \mathrm{H}_{2} \mathrm{O}$ solution ( $\left.20 \mathrm{mg} \mathrm{Ba} / \mathrm{ml}\right)$.

7. $\operatorname{Pr}\left(\mathrm{NO}_{3}\right)_{3} \cdot 6 \mathrm{H}_{2} \mathrm{O}$ salt.

8. Oxalic acia, crystals.

9. Zine sulfide, powder, phosphorescent grade, nonactivated.

10. 0.03 millicurie $\mathrm{Pb}^{210}, \mathrm{Bi}^{210}, \mathrm{Po}^{210}$ source solution.

11. 0.05 millicurie $\mathrm{Ra}^{226}$ source solution.

12. $\mathrm{Pa}^{231}$ source, naturally occurring 18 percent equivalent $\mathrm{Pa} 231$, 10 percent equivalent $\mathrm{Th}^{230}$ sample ( $\mathrm{Th}^{230}, \mathrm{~Pa}^{231}, \mathrm{Ac}^{227}, \mathrm{Th}^{227}$ source).

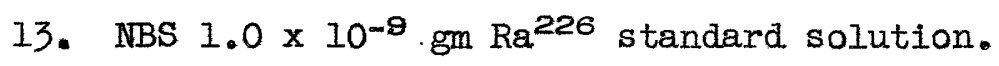

14. Standard pitchblende ore, MSOR, 44.96 percent uranium.

15. NBS standard 2230-1, MS-VL, 3.08 percent uranium.

16. NBS standard 2230-2, MS-L, 6.92 percent uranium.

17. NBS standard, 1.0 percent uranium

18. $\mathrm{Th}\left(\mathrm{NO}_{3}\right)_{4} \cdot 4 \mathrm{H}_{2} \mathrm{O}$ reagent (10 year old $\mathrm{Th}^{228}$ source).

19. $\operatorname{Th}\left(\mathrm{NO}_{3}\right)_{4} \cdot 4 \mathrm{H}_{2} \mathrm{O}$ equilibrium reagent ( 48 years old).

20. NBS standard, 1.0 percent thorium. 
Procedure for separation of nuclides

The sample, 1 gram or less depending on total activity and ease of solution, is fused to almost red heat with 4 to 5 grams of $\mathrm{Na}_{2} \mathrm{O}_{2}$ in a nickel crucible. The melt is taken up in water, neutralized with concentrated $\mathrm{HCl}$, and made up to an acidity of 1.0 normal with $\mathrm{HCl}$ and a total volume of $100 \mathrm{ml}$. With this treatment the sample should be completely in solution. Six milligrams of bismuth carrier is added, and the solution, at about $45^{\circ} \mathrm{C}$, is gassed with $\mathrm{H}_{2} \mathrm{~S}$.

The bismuth and polonium isotopes used for the $\mathrm{Rn}^{222}$ and $\mathrm{Pb}^{210}$ determination are separated from the solution when the bismuth sulfide carrier is precipitated and filtered from the solution (Rosholt, 1954). The $\mathrm{Rn}^{222}$ isotope was removed temporarily when the sample was fused.

The filtrate containing the uranium, protactinium, thorium, actinium, radium and lead isotopes is made almost free of $\mathrm{H}_{2} \mathrm{~S}$ by evaporation on a hot plate to a volume of approximately $80 \mathrm{ml}$. Ten arops of $1+1 \mathrm{H}_{2} \mathrm{SO}_{4}, 10 \mathrm{mg}$ of zirconium carrier, $3 \mathrm{ml}$ of $\mathrm{Na}_{4} \mathrm{P}_{2} \mathrm{O}_{7}$ are added separately to the filtrate and the solution is boiled gently for 1 to 2 minutes while the $(\mathrm{ZrO})_{2} \mathrm{P}_{2} \mathrm{O}_{7} \cdot \mathrm{ThP}_{2} \mathrm{O}_{7}$ precipitate is forming (Carney and Campbe11, 1914). The hot solution containing the precipitate is immediately centrifuged, the supernatant liquid. poured off, and the time recorded. The precipitate is washed with distilled. $\mathrm{H}_{2} \mathrm{O}$, centrifuged, and wash supernatant combined with the centrifugate. The precipitate is retained for either the $\mathrm{Th}^{230}$ determination or the $\mathrm{Th}^{232}$ determination where $\mathrm{Ra}^{224}$ is allowed to build up. This method for $\operatorname{Th}^{232}$ is used where the activity of $\mathrm{Bi}^{212}-\mathrm{Po}^{212}$ is too low for accurate measurement as previously described (Rosholt, 1954). 
1 milliliter of $\mathrm{Na}_{4} \mathrm{P}_{2} \mathrm{O}_{7}$ reagent are added to the gently boiling centrifugate, and the solution centrifuged and washed again. The centrifugate is adjusted to a $\mathrm{pH}$ of 3 with $\mathrm{HH}_{4} \mathrm{OH}$, cooled and gassed with $\mathrm{H}_{2} \mathrm{~S}$ for 5 minutes while 150 $\mathrm{mg}$ of $\mathrm{ZnS}$ is added. An excess of sulfide ion is required to adsorb completely the $\mathrm{Pb}^{212}$ contained in the solution on the $\mathrm{ZnS} ; \mathrm{Bi}^{212}$ and $\mathrm{Po}^{212}$ are also adsorbed. The zine sulfide is filtered from the solution and the time recorded. Twenty milligrams of barium carrier is added and 3 drops of $1+1$ $\mathrm{H}_{2} \mathrm{SO}_{4}$ added precipitating $\mathrm{BaSO}_{4} \cdot \mathrm{RaSO}_{4}$. The precipitate is allowed to settle. An additional $150 \mathrm{mg}$ of zinc sulfide phosphor is added, the slurry mixed, filtered, washed, mounted, and dried.

\section{Measurement of $\mathrm{Th}^{230}$ and $\mathrm{Pa}^{231}$}

The praseodymium oxalate carrier precipitate will contain the $\operatorname{Th}^{230}$ along with the $\mathrm{Pa}^{231}, \mathrm{Ac}^{227}$, and $\mathrm{Th}^{227}$ alpha emitters when products of the $\mathrm{U}^{235}$ decay series are present and the $\mathrm{Th}^{232}$ and $\mathrm{Th}^{228}$ alpha emitters if any $\mathrm{Th}^{232}$ decay series is present. Some Bi211 alpha activity may be present depending on the amount of $U^{235}$ series decay products in the sample and the time elapsed. since the thorium separation because $\mathrm{Pb}^{211}-\mathrm{Bi}^{211}$ decaying with a 36.1 -minute half-life is carried along with the thorium isotopes.

The counting rate of the precipitate is measured at day-to-day intervals for 6 to 10 days. Long counting measurement periods are used for determining these rates in order to establish the amount of $\mathrm{Ra}^{223}$ growth from $\mathrm{Th}^{227}$ for the $\mathrm{Pa}^{231}$ determination. The $\mathrm{Th}^{230}$ nuclide and $\mathrm{Pa}^{231}$ group are resolved by use of a plot of a straight-line equation of the form:

$$
\mathrm{C}_{\mathrm{T}}=\mathrm{C}_{\mathrm{Pa} 231} f_{\mathrm{Th}^{227}}+\mathrm{C}_{\mathrm{Th}^{230}}
$$


where $C_{T}$ is the measured counting rate

$\mathrm{C}_{\mathrm{Pa}^{231}}$ is the $\mathrm{Pa}^{231}$ counting ratie

$\mathrm{C}_{\text {Th230 }}$ is the $\mathrm{Th}^{230}$ counting rate

$f_{T_{h}} 227$ is the function of the growth of $R_{2} 223$ and disintegration products from $\mathrm{Th}^{227}$.

The time at which the $\operatorname{Pr}_{2}\left(\mathrm{C}_{2} \mathrm{O}_{4}\right)_{3} \cdot \mathrm{IOH}_{2} \mathrm{O}$ precipitate was filtered is used as the zero time from which the function of Th227 is calculated. The function of $T^{227}$ with time is shown in figure 2 and is plotted from the data obtained from calculation 4. The plot of the straight-line equation is shown in figure 3. The intercept of the $\mathrm{Th}^{230}-\mathrm{Pa}^{231}$ Iine at the zero axis is the counting rate of $\mathrm{Th}^{230}$ and the slope of the line is the $\mathrm{Pa}^{231}$ counting rate.

The $\mathrm{Th}^{230}$ and $\mathrm{Pa}^{231}$ analysis by this method is limited to samples which do not contain quantities of the Th232 decay series in excess of $1 / 50$ for the ratio of percent $\mathrm{Th}^{232} /$ percent equivalent $\mathrm{Pa}^{231}$. Quantities of $\mathrm{Th}^{232}$ series in excess of this amount can usually be detected in the $\mathrm{Bi}_{2} \mathrm{~S}_{3}$ precipitate used for the $\mathrm{Rn}^{222}$ analysis. The lower analytical limit for $\mathrm{Th}^{230}$ and $\mathrm{Pa} 231$ is approximately 0.01 percent equivalent.

Efficiency calculation and standardization of the $\mathrm{Th}^{230}, \mathrm{Pq}^{231}$, and $\mathrm{Ra}^{223}$ measurements $--\mathrm{Th}^{230}, \mathrm{~Pa}^{231}, \mathrm{Ac}^{227}$, and $\mathrm{Th}^{227}$ are separated from 4 grams of a natural occurring source sample which contains 18 percent equivalent $\mathrm{Pa}^{231}$ and immediate disintegration products, 10 percent equivalent $\mathrm{Th}^{230}, 13$ percent equivalent $\mathrm{Ra}^{226}$, and 0.1 percent uranium. The sample of high-grade $\mathrm{Pa}^{231}$ source is digested with $20 \mathrm{ml}$ of $\mathrm{HCl}$ for half an hour, filtered, and the soluble portion retained. Bismuth and polonium isotopes are removed from the solution, and the Th230, $\mathrm{Pa}^{231}, \mathrm{Ac}^{227}$, and $\mathrm{Th}^{227}$ separated by coprecipitation with $(\mathrm{ZrO})_{2} \mathrm{P}_{2} \mathrm{O}_{7}$ carrier. The pyrophosphate precipitate is dissolved in oxalic acid, and the solution is adjusted to a $\mathrm{pH}$ of 3 with $\mathrm{NH}_{4} \mathrm{OH}$. Two 


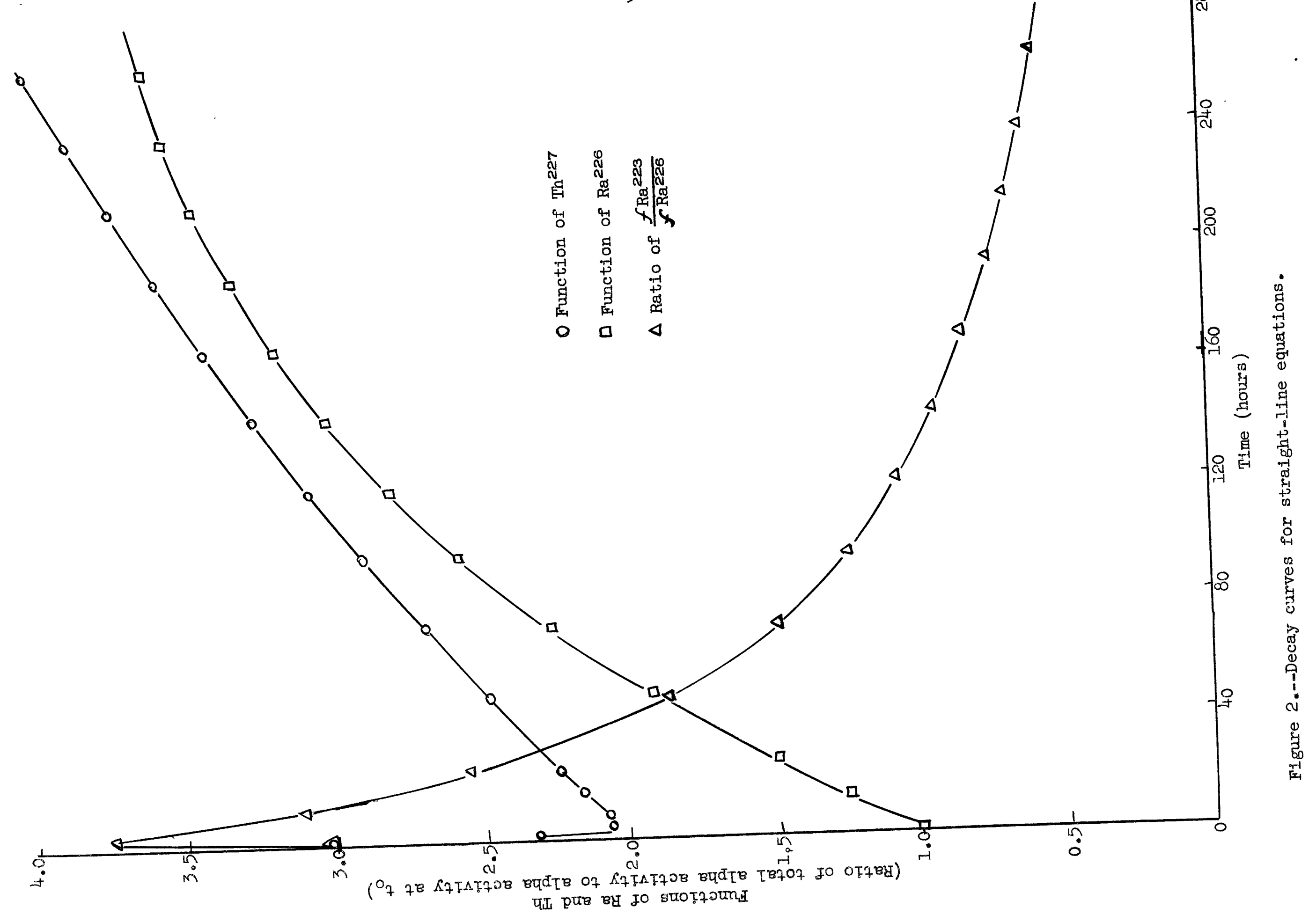




hundred milligrams of zine sulfide and 10 drops of HF are added, the slurry is stirred for 5 minutes, fiztered, whed, and dried, and the time recorded.

Smali fractions of this active zinc sufide are used for the source of the $\mathrm{Th}^{230}$ and $\mathrm{Pa}^{231}-\mathrm{Ac}^{227}-\mathrm{Th}^{227}$. Each individual source which should represent 300-1000 alpha-particle disintegrations per minute is thinly spread on the center of a 50-mm aluminum ring-supported paper and placed in the automatic sample changing scintillation detector. The alpha particle counting rate is measured at approximately once a day for 10 to 15 days. The straightline equation for $\mathrm{Th}^{230}$ and $\mathrm{Pa}^{231}$ is calculated and plotted using the data from these measurements. The counting rates of the $\mathrm{Th}^{230}, \mathrm{~Pa}^{231}-\mathrm{Ac}^{227}-\mathrm{Th}^{227}$, and $\mathrm{Ra}^{223}$ are determined from this plot. These counting rates are then calibrated to total alpha particle disintegration rates using the appropriate factor of detection efficiency for the phototube used from table 1.

The active zinc sulfide source is transferred to a nickel crucible and carried through the separation steps for the normal $\mathrm{Th}^{230}-\mathrm{Pa}^{231}$ and $\mathrm{Ra}^{226}-\mathrm{Ra}^{223}$ analyses. The counting rates of the $\mathrm{Th}^{230}, \mathrm{~Pa}^{231}$, and $\mathrm{Ra}^{223}$ isotopes are compared to the total alpha particle disintegration rates measured in the zine sulfide source. The efficiencies of the $\mathrm{Th}^{230}$ and $\mathrm{Pa}^{231}$ analyses are calculated and the standard counting rates of $\mathrm{Th}^{230}$ and $\mathrm{Pa} 231$ determined (calculation 9). The standard counting rates of $\mathrm{Th}^{230}$ and $\mathrm{Pa} 231$ are also determined from several standard uranium ore samples. Table 2 shows these efficiency values and the comparison of the separately determined standard counting rates.

Greater variation exists between each determination of the efficiency of the measurement of $\mathrm{Th}^{230}, \mathrm{~Pa}^{231}$, and $\mathrm{Ra}^{223}$ than between each determination for the other nuclides because of the difficulty of adsorbing sufficient carrierfree activity of these nuclides. 
Table 1.--Values used for calculation of the detection efficiencies of the 3-inch photomultiplier tube,

\begin{tabular}{|c|c|c|c|c|c|c|}
\hline $\begin{array}{l}\text { Photo- } \\
\text { tube } \\
\text { used }\end{array}$ & $\begin{array}{l}\text { Ra226 activity in } \\
\text { Zns source } \\
\text { detected by photo- } \\
\text { tribe }(\mathrm{c} / \mathrm{min})\end{array}$ & $\begin{array}{l}\text { Raz28 content by } \\
\text { radon train } \\
\text { analysis } 1 / \\
\left(10^{-9} \mathrm{~g} \text { of Ras }\right)\end{array}$ & $\begin{array}{l}\text { Ra228 activity cal- } \\
\text { culated from Ra } \mathrm{Ra}^{228} \\
\text { content (dis/min) }\end{array}$ & $\begin{array}{l}\text { Detection efficiency } \\
\text { (ratio of measured } \\
\text { activity to theoret- } \\
\text { ical activity) }\end{array}$ & $\begin{array}{l}\text { Ratio: } P^{210} \text { activity in } \\
\text { phototube normalized to } \\
\text { Po 210 activity in tube } 4 \\
\text { (av. } 14 \mathrm{ZnS} \text { sources) }\end{array}$ & $\begin{array}{l}\text { Normalized ratio } \\
\text { x detection } \\
\text { efflclency of } \\
\text { tube } 4\end{array}$ \\
\hline 1 & $3885 \pm 36$ & $1.885 \pm 0.015$ & $4081 \pm 32$ & $0.952 \pm 0.012$ & $0.984 \pm 0.008$ & $0.955 \pm 0.018$ \\
\hline 3 & $5040 \pm 40$ & $2.397 \pm 0.011$ & $5190 \pm 24$ & $0.971 \pm 0.009$ & $0.998 \pm 0.003$ & $0.969 \pm 0.016$ \\
\hline 4 & $3475 \pm 26$ & $1.652 \pm 0.024$ & $3577 \pm 52$ & $0.971 \pm 0.016$ & 1.00 & $0.971 \pm 0.016$ \\
\hline 5 & $5239 \pm 45$ & $2.607 \pm 0.021$ & $5644 \pm 45$ & $0.928 \pm 0.011$ & $0.955 \pm 0.016$ & $0.928 \pm 0.022$ \\
\hline 6 & $4168 \pm 52$ & $2.003 \pm 0.020$ & $4336 \pm 43$ & $0.961 \pm 0.015$ & $0.989 \pm 0.005$ & $0.960 \pm 0.017$ \\
\hline
\end{tabular}

1/ Radium analyses by Sylvia P. Furman, U. S. Geological survey. 
Table 2.--Experimental alpha activity constants for $\mathrm{Th}^{230}$ and $\mathrm{Pa} 231$ determinations.

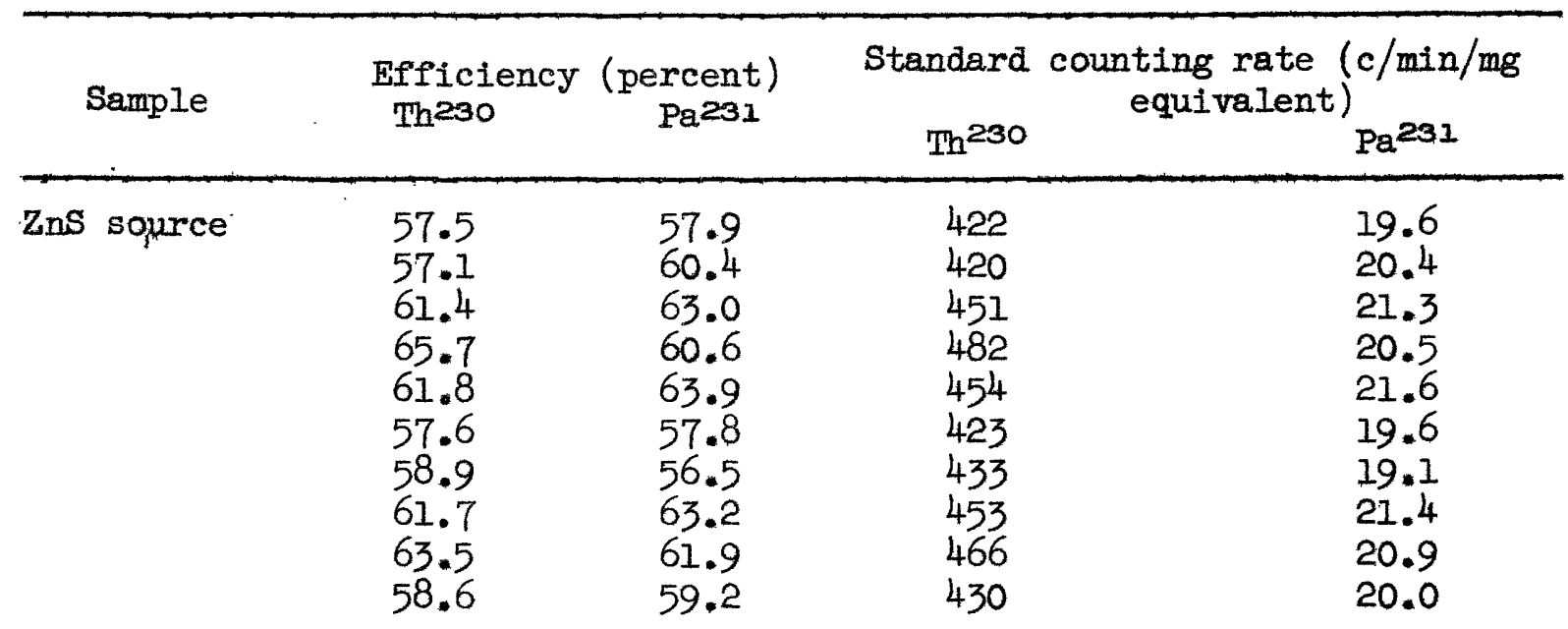

Average and

standard

deviation

$60.4 \pm 2.960 .4 \pm 2.4 \quad 444 \pm 21$

$20.4 \pm 0.8$

MS-OR $(44.96 \% \mathrm{U})$

467

20.4

$\operatorname{MS}-\mathrm{I}(6.92 \% \mathrm{U})$

480

22.1

MS-VL $(3.08 \% \mathrm{U})$

434

468

447

462

449

468

20.3

21.7

20.8

22.0

21.0

20.4

$\operatorname{NBS}(1.0 \% \mathrm{U})$

433

470

20.3

21.0

Average and

standard.

deviation

$458 \pm 16$

$21.0 \pm 0.7$ 
Measurement of $\mathrm{Ra}^{226}, \mathrm{Ra}^{223}$, and $\mathrm{Rn}^{222}$

The barium sulfate carrier precipitate will contain the Ra226 alpha emitter and the $\mathrm{Ra}^{223}-\mathrm{Rn}^{219}-\mathrm{PO}^{215}-\mathrm{Bi}^{211}$ alpha emitters in the presence of the $\mathrm{U}^{235}$ decay series, and the $\mathrm{Ra}^{224}-\mathrm{Rn}^{220}-\mathrm{PO}^{216}$ alpha emitters when the Th ${ }^{232}$ decay series is present. The analysis of $\mathrm{Ra}^{226}$ and $\mathrm{Ra}^{223}$ by this method is limited to the same restrictions for the ratio of $\mathrm{Ra}^{223} / \mathrm{Th}^{232}$ as those imposed for the $\mathrm{Th}^{230}-\mathrm{Pa}^{231}$ analysis.

The counting rate of the precipitate is measured at approximately equally spaced intervals such that 5 to 7 measurements are made over a period of 2 to 4 days. Long periods of measurement are required in order that the amount of $\mathrm{Ra}^{223}$ decaying may be calculated. The $\mathrm{Ra}^{226}$ and $\mathrm{Ra}^{223}$ components are resolved by use of a plot of a straight-line equation of the form:

$$
\begin{array}{r}
\text { since } c_{\mathrm{T}}=\mathrm{C}_{\mathrm{Ra}^{223}} f_{\mathrm{Ra}^{223}}+\mathrm{C}_{\mathrm{Ra}} 226 f_{\mathrm{Ra}} 226 \\
\text { then } \mathrm{c}_{\mathrm{T}} / f_{\mathrm{Ra}^{226}}=\mathrm{C}_{\mathrm{Ra}^{223}}\left(f_{\mathrm{Ra}^{223}} / f_{\mathrm{Ra}^{226}}\right)+\mathrm{C}_{\mathrm{Ra}} 226
\end{array}
$$

where $C_{T}$ is the measured counting rate

$\mathrm{C}_{\mathrm{Ra} 223}$ is the $\mathrm{Ra}^{223}$ counting rate

$\mathrm{C}_{\mathrm{Ra}^{226}}$ is the $\mathrm{Ra}^{226}$ counting rate

$f_{\mathrm{Ra}^{223}}$ is the function of the decay of $\mathrm{Ra}^{223}$ and decay products

$f_{\mathrm{Ra}^{226}}$ is the function of the growth of $\mathrm{Rn}^{222}$ and decay products.

The time of the $\mathrm{BaSO}_{4}$ filtration is used as the zero time from which these functions are calculated. The function of $\mathrm{Ra}^{226}$ and the ratio of the function of $\mathrm{Ra}^{223}$ to the function of $\mathrm{Ra}^{226}$ are shown in figure 2. They are plotted from the data obtained from calculations 5 and 6 . The plot of the straight-line equation is shown in figure 3. The intercept of the $\mathrm{Ra}^{226}-\mathrm{Ra}^{223}$ Iine at the $f_{\mathrm{Ra} 223} / f_{\mathrm{Ra} 266}$ value of zero is the counting rate of $\mathrm{Ra}^{226}$ and the slope of the line is the $\mathrm{Ra}^{223}$ counting rate. 
The $\mathrm{Ra}^{223}$ content determined from this preclpitate should agree rather sloseIy with the Pa23i sontent found In the Th230-Pa23I precipitate. The average of these two valueg is then lised for the $\mathrm{Pa}^{231}$ content.

The analysis for $\mathrm{Ra}^{223}$ by scintizlation method is restricted to samples which do rot contain mare than $20 \mathrm{mg}$ of barium plus strontium. The same restriction regarding the presence of the $\mathrm{Th}^{232}$ decay series products exists for $\mathrm{Ra}^{226}-\mathrm{Ra}^{223}$ as for $\mathrm{Th}^{230}-\mathrm{Pa}^{23 I}$. In the special case where $\mathrm{Ra}^{228}$, Th228, and $\mathrm{Ra}^{224}$ from the $\mathrm{Th}^{232}$ decay ser亡es and $\mathrm{Re}^{226}$ are present in a sample that contains Th ${ }^{228}$ exceeding 95 percent of the total initial alpha activity in the thorium precipitate, the straight.-line equations modified for $\mathrm{Ra}^{224}$ presence may be used to calculate the $\mathrm{Ra}^{226}, \mathrm{Th}^{228}$, and $\mathrm{Ra}^{224}$ content of the sample. In all other limited cases the Ra226 analysis is performed by the radon train method. The lower analytical limit for $\mathrm{Ra}^{226}$ using the scintillation counter is approximately 0.001 percent equivalent。

The method for the determination of $\mathrm{Rn}^{222}$ has been described (Rosholt, 1954).

Efficiency calculation and standardization of $\mathrm{Ra}^{226}-\mathrm{Ra}^{223}$ measurement and $\mathrm{Rn}^{222}$ measurement. - The $\mathrm{Ra}^{226}$ and $\mathrm{Rn}^{222}$ source is a $10^{-7}$ curie aliquot of the $\mathrm{Ra}^{226}$ solution. A 50-ml volume containing this source is boiled under partial vacuum while flushing with air to remove the radon. Radon decay products are removed from the solution by adsorption on zinc sulfide at a pH of 1 to 3. It was determined that more than 99 percent of the bismuth and. polonium activity is adsorbed on zinc sulfide up to an acidity of 0.5 normal HC1. Two drops of $1+1 \mathrm{H}_{2} \mathrm{SO}_{4}$ and $150 \mathrm{mg}$ of zinc sulfide are added, and the slurry is filtered, washed, and dried. The time of precipitation is recorded. In the presence of sulfate ion the zinc sulf:ide will adsorb an appreciable amount of $\mathrm{RaSO}_{4}$ from the solution. Small fractions of this carrier-free 
active zinc sulfide are made into separate samples of the desired amount of activity and prepared for counting in the same manner as with the Th230 source.

The counting rates of the carrier-free sources are measured at regular intervals for a few hours. The amount of pure $\mathrm{Ra}^{226}$ activity detected is determined by extrapolation of the increasing counting rate back to the time of filtration. Several of the $\mathrm{RaSO}_{4}$ sources are used to calculate the detection efficiency of the preceding measurements. These sources are dissolved in $\mathrm{HCl}$, and a radium analysis of the solution is performed by the radon train method (Curtiss and Davis, 1943). The value of the Ra226 activity determined by the photomultiplier tube measurement is compared to the total $\mathrm{Ra} 226$ activity calculated from the $\mathrm{Ra}^{226}$ content determined by the conventional radium analysis (calculation 8 ). The ratio of these two values is used as the detection efficiency factor (table 1). A National Bureau of Standards $10^{-9}-\mathrm{g} \mathrm{Ra}^{226}$ standard solution is used to calibrate the radon train analysis. $\mathrm{Rn}^{222}$ is allowed to build up for 3 days or more in the active zinc sulfide sources which are to be used for over-all efficiency calculation. The counting rate of the $\mathrm{Ra}^{226}$ and $\mathrm{Rn}^{222}$ plus $\mathrm{PO}^{218}$ and $\mathrm{PO}^{214}$ which are almost in equilibrium with the $\mathrm{Rn}^{222}$ in the source is determined. For a radon build-up period of 3 to 5 days, the product of 0,334 and the difference between the original activity of $\mathrm{Ra}^{226}$ and the latter activity of the $\mathrm{Ra}^{226}, \mathrm{Rn}^{222}, \mathrm{PO}^{218}$ and $\mathrm{PO}^{214}$ is the activity of $\mathrm{Rn}^{222}$ at the time of the latter measurement (see calculation 11). The activities of both the $R a^{226}$ and $\mathrm{Rn}^{222}$ are corrected to yield total disintegration rates by use of the appropriate detection efficiency factor.

The active zinc sulfide is immediately transferred to a nickel crucible. The daughter products of $\mathrm{Rn}^{222}$ are separated and the counting rate of the 
$\mathrm{Bi}_{2 \mathrm{~S}_{3}}$ precipitate for $\mathrm{Rn}^{222}$ analysis is determined in the usual manner. The solution is carried through the separation procedure to the isolation of the radium isotopes. The $(\mathrm{ZrO})_{2} \mathrm{P}_{2} \mathrm{O}_{7}$ carrier was precipitated and separated even though no thorium isotopes are present in order to simulate the actual conditions of analysis of a sample. The counting rate of $\mathrm{Ra}^{226}$ is measured and compared to the total disintegration rate of the $\mathrm{Ra}^{226}$, thus allowing calculations of the efficiency and the standard counting rate of the $\mathrm{Ra}^{228}$ analysis (calculation 9).

The $\mathrm{Ra}^{223}$, allowed to build up in the carrier-free $\mathrm{Th}^{230}-\mathrm{Fa}^{231}$ precipitate, is carried through the radium isotope procedure. The efficiency and standard counting rate of $\mathrm{Ra}^{223}$ and its immediate daughters are calculated from this data (calculation 9).

Uraniferous samples will contain both $\mathrm{Ra}^{228}$ and $\mathrm{Ra}^{223}$ isotopes. The counting rates of $\mathrm{Ra}^{226}$ and $\mathrm{Ra}^{223}$ plus its immediate daughters in the standard ore samples are compared to the theoretical counting rates of these isotopes calculated from the over-all efficiency values of these determinations and the data is shown in table 3 .

The over-all efficiency of the $\mathrm{Rn}^{222}$ determination is calculated from the ratio of the counting rate of the $\mathrm{PO}^{214}$ in the $\mathrm{BI}_{2} \mathrm{~S}_{3}$ precipitate and the total disintegration rate of the $\mathrm{Rn}^{222}$ computed on the $\mathrm{RaSO}_{4} \cdot \mathrm{ZnS}$ source at the time of fusion. The standard counting rate is calculated from this efficlency value (calculation 10), and the values are shown in table 4 .

The determination of the standard counting rate of $\mathrm{Rn}^{222}$ using ore samples in which the determination is independent of $\mathrm{Rn}^{222}$ loss has been performed. A standard uranium ore in a nickel crucible is placed in a refrigerator freezing compartment at $-22^{\circ} \mathrm{C}$ to impound the radon. After the sample has remained in the freezer for three weeks, attaining approximately 98 percent 
Table 3.--Experimental alpha activity constants for Ra2as and Ra223 determinations.

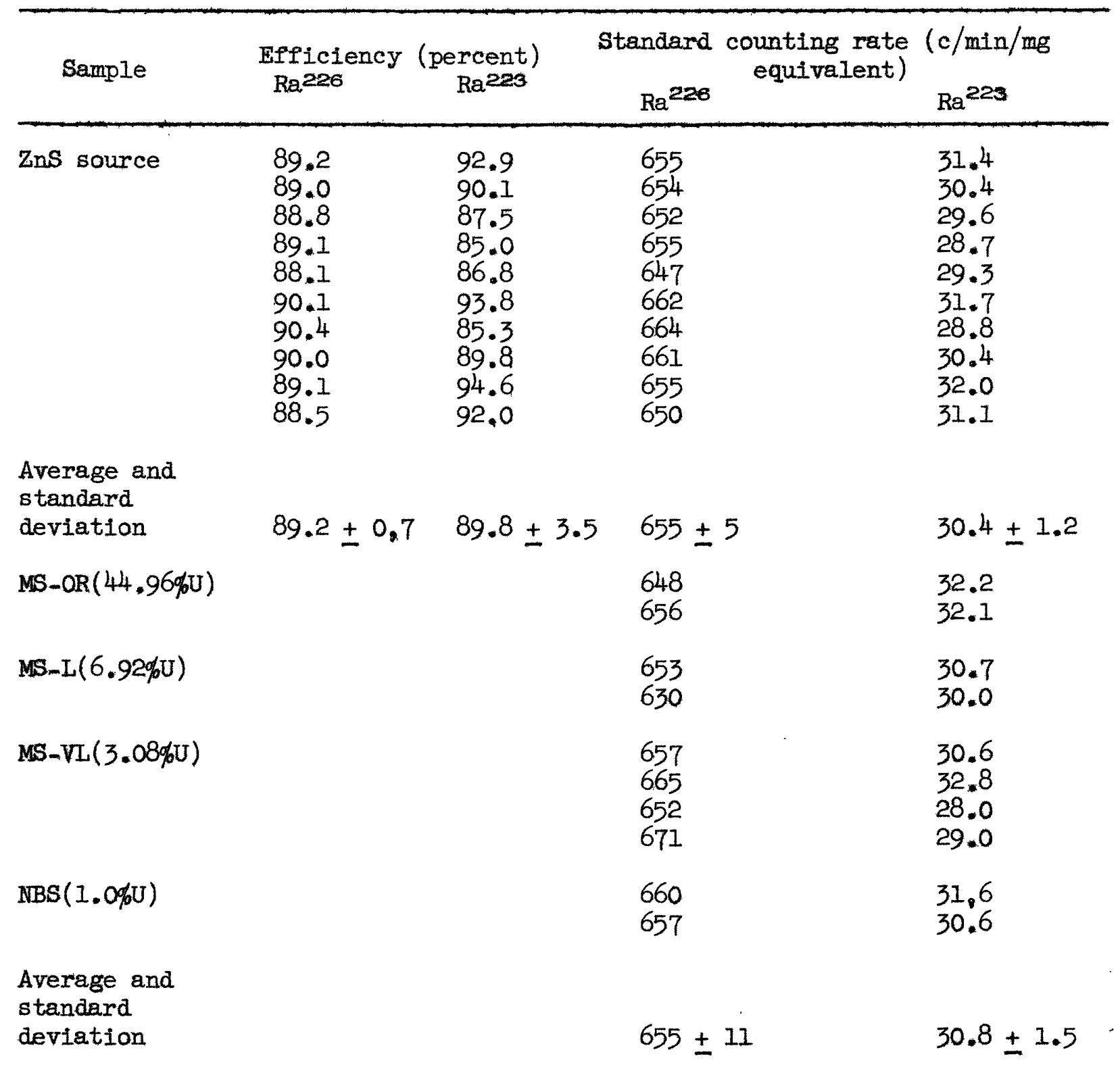


Table 4.--Experimental alpha activity constants for Rn 222 determination.

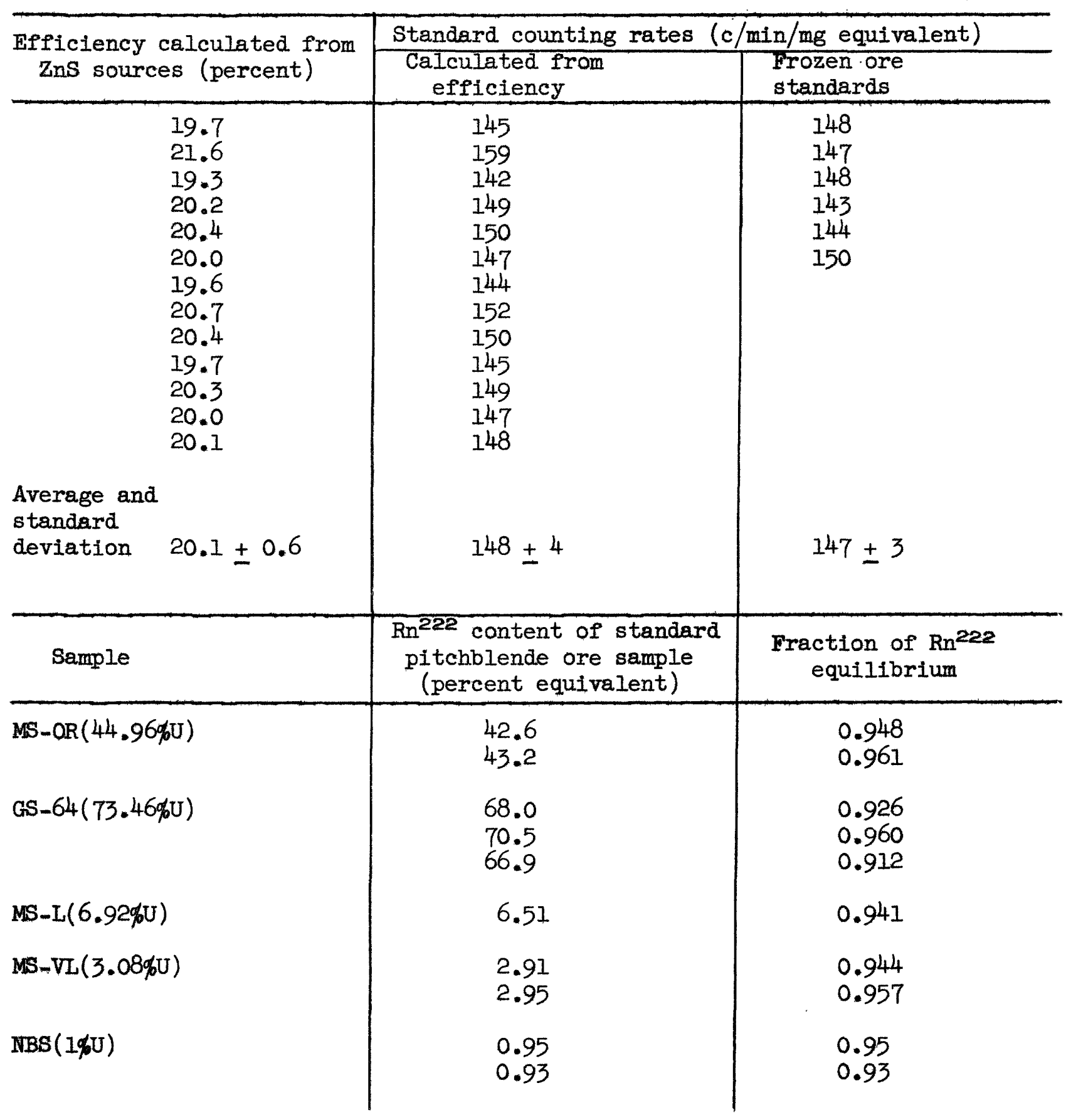


of its equilibrium content due to retention of more radon, it is immersed in liquid nitrogen for 12 to 14 days. As radon is frozen in the ore sample, greater than 99 percent equilibrium will be attained with the radium. The freezing point of radon is $-110^{\circ} \mathrm{C}$ whereas the liquid nitrogen temperature is $-196^{\circ} \mathrm{C}$. The sample is removed from its freezing environment, and a regular $\mathrm{Rn}^{222}$ analysis initiated immediately. The counting rate obtained is the standard counting rate of $\mathrm{Rn}^{222}$ and is compared to that obtained from the efficiency calculation in table 4. Table 4 also lists the $\mathrm{Rn}^{222}$ analyses of several standard ore samples at room temperature. The fraction of $\mathrm{Rn}^{222}$ in partial equilibrium with the $\mathrm{Ra}^{226}$ is calculated showing the magnitude of the $\mathrm{Rn}^{222}$ loss at room temperature.

Measurement of $\mathrm{Pb}^{210}$

The separation and measurement of $\mathrm{Pb}^{210}$ is performed as previously described (Rosholt, 1954). The assumption is made that 138 day half-life $\mathrm{Po}^{210}$ will be in equilibrium with $\mathrm{Pb}^{210}$ in geological samples, and the determination of the alpha activity of $\mathrm{PO}^{210}$ will be used to calculate the $\mathrm{Pb}^{210}$ content.

Efficiency calculation and standardization of $\mathrm{Pb}^{210}$ measurement.- $-\mathrm{A} 50-\mathrm{ml}$ solution of radioactively pure $\mathrm{Pb}^{210}-\mathrm{Bi}^{210}-\mathrm{Po}^{210}$ containing approximately $5 \times 10^{-8}$ curie of $\mathrm{PO}^{210}$ is adjusted to a $\mathrm{pH}$ of 2 to 3 . One-hundred-fifty milligrams of zinc sulfide is added to the solution. Greater than 99 percent of the bismuth and polonium isotopes will be adsorbed on the zinc sulfide. The slurry is filtered, washed, and dried. Small fractions of this active zinc sulfide, representing approximately 3000-5000 alpha particle disintegrations per minute, are prepared and counted in the same manner as described for the preceding nuclides. The counting rate is calibrated to total alpha 
particle disintegration rate using the appropriate efficiency correction factor for the phototube used.

The active zinc sulfide is transferred to a nickel crucible, 4 grams of $\mathrm{Na}_{2} \mathrm{O}_{2}$ added, and the sample carefully fused to almost red heat. Some Po210 will easily volatilize from the zinc sulfide and crucible if not continually in intimate contact with the $\mathrm{Na}_{2} \mathrm{O}_{2}$ flux while being heated. The normal $\mathrm{Pb}^{210}$ analysis is performed on the source, determining the counting rate of the $\mathrm{Po}^{210}$ in the $\mathrm{Bi}_{2} \mathrm{~S}_{3}$ precipitate. The ratio of the counting rate of the $\mathrm{Po}^{210}$ in the $\mathrm{Bi}_{2} \mathrm{~S}_{3}$ precipitate to the total aipha particle disintegration rate calculated on the zinc sulfide source is the over-all efficiency value for the $\mathrm{Pb} 210$ determination. The standard counting rate of $\mathrm{Pb}^{210}$ is calculated from this efficiency value (calculation 9).

Table 5 shows both of these values along with $\mathrm{Pb}^{210}$ analyses on several standard ore samples. The ratio of the equivalent $\mathrm{Pb}^{210}$ content to the equivalent $\mathrm{Ra}^{226}$ content is calculated, thus indicating the magnitude of the $\mathrm{Rn}^{222}$ loss from the samples over a pericd of several years.

\section{Measurement of $\mathrm{Th}^{232}$}

The $\mathrm{ZnS} \cdot \mathrm{BaSO}_{4}$ precipitate prepared for the $\mathrm{Th}^{232}$ analysis initially will contain the alpha emitters $\mathrm{Ra}^{224}, \mathrm{Rn}^{220}$, and $\mathrm{PO}^{216}$. The $\mathrm{Bi}^{212}$ and $\mathrm{PO}^{212}$ activity will begin to build up as the $\mathrm{Pb}^{212}$ builds up. The time at which the activity starts to increase is the time when the zinc sulfide used to adsorb the originally present $\mathrm{Pb}^{212}-\mathrm{Bi}^{212}$ was filtered from the solution.

The precipitate is measured in the same manner described for the preceding nuclides. The observed counting rate is corrected to obtain the peak counting rate that $\mathrm{Ra}^{224}$ and its daughter produets would have from figure 4 . The calculation of the fraction of Ra224 built up from zero activity from $\mathbb{T h}^{228}$ is 
Table 5.--Experimental alpha activity constants for $\mathrm{Pb}^{210}$ determination.

\begin{tabular}{|c|c|c|}
\hline Sample & Efficiency (percent) & $\begin{array}{l}\text { Standard counting rate } \\
\text { (c/min/mg equivalent) }\end{array}$ \\
\hline ZnS source & $\begin{array}{l}26.9 \\
26.4 \\
27.1 \\
27.3 \\
26.8 \\
26.7 \\
26.8 \\
26.5 \\
27.3 \\
27.0\end{array}$ & $\begin{array}{l}198 \\
194 \\
199 \\
200 \\
197 \\
196 \\
197 \\
195 \\
200 \\
198\end{array}$ \\
\hline $\begin{array}{l}\text { Average and } \\
\text { standard } \\
\text { deviation }\end{array}$ & $26.8 \pm 0.3$ & $197 \pm 2$ \\
\hline Sample & $\begin{array}{l}\mathrm{Pb}^{210} \text { content of standard } \\
\text { pitchblende ore sample } \\
\text { (percent equivalent) }\end{array}$ & $\begin{array}{l}\text { Fraction of } \mathrm{Pb}^{210} \\
\text { equilibrium }\end{array}$ \\
\hline MS_OR $(44.96 \% \mathrm{U})$ & $\begin{array}{l}42.8 \\
42.6 \\
42.0\end{array}$ & $\begin{array}{l}0.953 \\
0.948 \\
0.934\end{array}$ \\
\hline GS-64 (73.46\%U) & $\begin{array}{l}70.2 \\
69.6 \\
68.4\end{array}$ & $\begin{array}{l}0.957 \\
0.948 \\
0.945\end{array}$ \\
\hline$M S=I(6.92 \% U)$ & 6.41 & 0.927 \\
\hline MS-VL $(3.08 \% \mathrm{U})$ & $\begin{array}{l}2.83 \\
2.88 \\
2.86 \\
2.89\end{array}$ & $\begin{array}{l}0.919 \\
0.935 \\
0.929 \\
0.939\end{array}$ \\
\hline $\operatorname{NBS}(1 \% \mathrm{U})$ & $\begin{array}{l}0.96 \\
0.96\end{array}$ & $\begin{array}{l}0.96 \\
0.96\end{array}$ \\
\hline
\end{tabular}




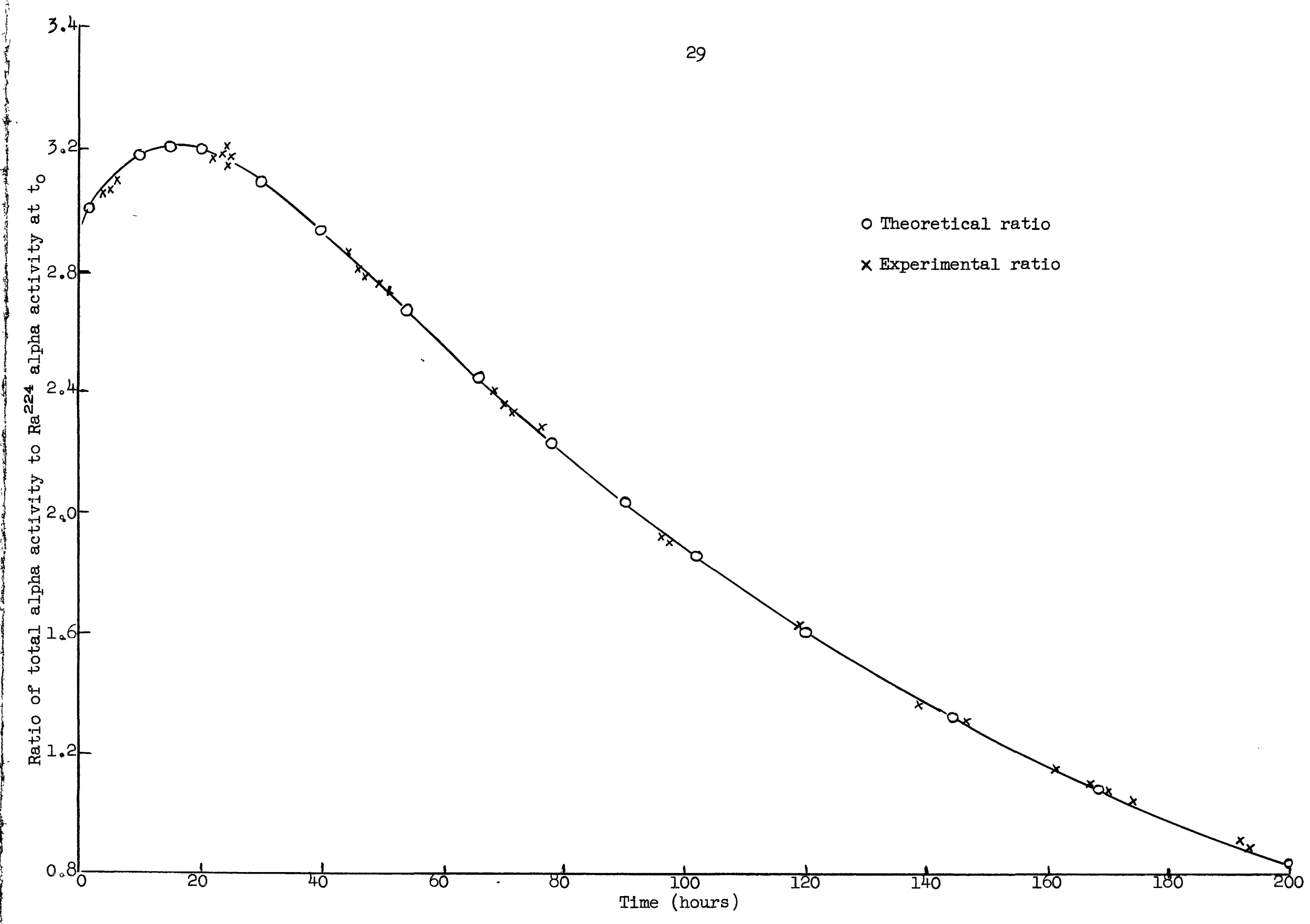

Figure 4.--Build-up and decay curve of $\mathrm{Ra}^{224}$. 

performed knowing the time elapsed between the first thorium separation and the second thorium separation isolating the $\mathrm{Ra}^{224}$ (calculation 11). The corrected counting rate of the sample would be the peak counting rate that $\mathrm{Ra}^{224}$ and its products would have at equilibrium with the $\mathrm{Th}^{228}$.

Correction should be made for the contribution of $\mathrm{Ra}^{223}$ and its daughter products in the $U^{235}$ decay series if the sample has an appreciable uranium content as the separation of $\mathrm{Ra}^{223}$ is identical to that of $\mathrm{Ra}^{224}$. An analysis of the uranium content of the sample is usually available before the thorium determination is undertaken. Uranium series equilibrium and the theoretical ratio of $U^{235}$ to $U^{238}$ is assumed. In the time allowed for the $\mathrm{Ra}^{224}$ build-up, no measureable $\mathrm{Ra}^{226}$ will build up from the $\mathrm{Th}^{230}$ accompanying the $\mathrm{Th}^{232}-\mathrm{Th}^{228}$. The restrictions on the radium isotope contamination are limited to samples where the uranium-to-thorium ratio is not in excess of approximately 5 to 1. At present the lower analytical limit where this ratio is low is approximately 1 miterogram of $\mathrm{Th}^{232}$ contained in the sample.

Efficiency calculation and standardization of $\mathrm{Th}^{232}$ determination.-A $\operatorname{Th}\left(\mathrm{HO}_{3}\right)_{4} \cdot 4 \mathrm{H}_{2} \mathrm{O}$ reagent which is at least $I$ month old is used as the source of the isotopes for this efficiency measurement. The reagent does not necessarily have to be in equilibrium with respect to $\mathrm{Th}^{232}-\mathrm{Ra}^{228}-\mathrm{Th}^{228}$. Thirty to 50 milligrams of the reagent is used as the source of the isotopes for this efficiency measurement,

The reagent is dissolved in $25 \mathrm{ml}$ of water and made up to an acidity of $0.6 \mathrm{~N} \mathrm{HCl}$ and a temperature of $45^{\circ} \mathrm{C}$. One-hundred and fifty milligrams of zine sulfide is added to adsorb the $\mathrm{Bi}^{212}-\mathrm{Po}^{212}$ isotopes quantitatively. The slurry is filtered, washed with $0.4 \mathrm{~N} \mathrm{HCl,} \mathrm{washed} \mathrm{with} \mathrm{alcohol,} \mathrm{mounted,} \mathrm{and}$ dried. The time of filtration is recorded. The counting rate of the active zinc sulfide is measured for several continuous intervals. The counting 
rates are extrapolated back to the time of filtration. This value is the alpha particle counting rate for $\mathrm{Bi}^{212} \mathrm{PO}^{212}$ and for $\mathrm{Th}^{228}$.

$\mathrm{Bi}^{212}-\mathrm{Po}^{212}$ is allowed to build up in the solution from which the zinc sulfide was filtered. Equilibrium of the $\mathrm{Bi}^{212}$ with $\mathrm{Th}^{228}$ can be assured when all of the $\mathrm{Bi}^{212}-\mathrm{Po}^{212}$ activity in the precipitate has decayed. If the $\mathrm{PO}^{230}$ activity is in excess of 0.1 percent of the original $\mathrm{Bi}^{212}-\mathrm{PO}^{212}$ activity, it should be subtracted from the latter.

The solution is made to $1.0 \mathrm{~N} \mathrm{HCl}$ at $60^{\circ} \mathrm{C}$ and $1 \mathrm{ml}$ each of the $\mathrm{Bi}_{2} \mathrm{O}_{3}$, $\mathrm{Pb}\left(\mathrm{NO}_{3}\right)_{2}$ and $\mathrm{FeCl}_{3}$ solutions are added. A regular thorium analysis by coprecipitation of $\mathrm{Bi}^{212}-\mathrm{Po}^{212}$ with $\mathrm{Bi}_{2} \mathrm{~S}_{3}$ is performed. The filtrate from this separation is also carried through the procedure for thorium analysis by the measurement of $\mathrm{Ra}^{224}$ and its products.

The standard counting rate for $\mathrm{Bi}^{212}-\mathrm{Po}^{212}$ activity adsorbed on $150 \mathrm{mg}$ of zinc sulfide is determined by following exactly the same procedure of $\mathrm{Bi}^{212}-\mathrm{Po}^{212}$ adsorption using several accurately weighed 20 to $30 \mathrm{mg}$ portions of the 48-year-old thorium nitrate salt. These standard values and the average are shown in table 6 . This average value of $\mathrm{c} / \mathrm{min} / \mathrm{mg}$ equivalent $\mathrm{Bi}^{212}$ is used in calculation 11 Instead of the specific activity of $\pi^{232}$ because of the difficulty involved in the determination of the detection efficiency for the measurement of $\mathrm{Bi}^{212}-\mathrm{Po}^{212}$ adsorbed on zinc sulfide.

The efficiencies and standard counting rates of the two methods are calculated (calculation 1I). These efficiencies, standard counting rates, the counting rates of standard ore samples, and a 48-year-old equilibrium $\mathrm{Th}\left(\mathrm{NO}_{3}\right)_{4} \cdot 4 \mathrm{H}_{2} \mathrm{O}$ reagent are shown and compared in table 6. 
Table 6.--Experimental alpha activity constants for $\operatorname{Th}^{232}$ determination.

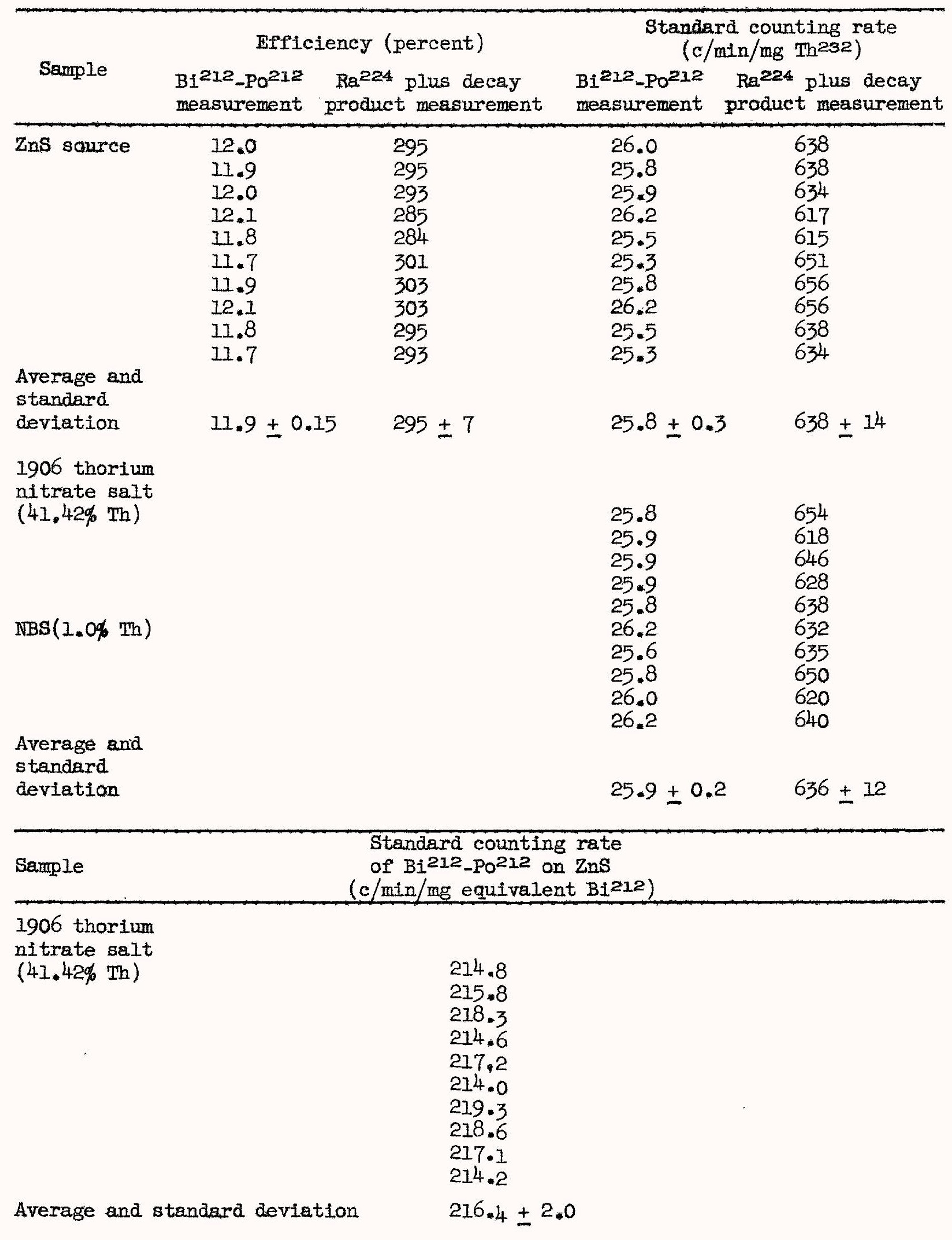




\section{CALCULATIONS}

The decay constants used are taken from (Flanagan and Senftle, 1954):

1. Specific activities of uranium isotopes and equivalent amounts of each decay product (Kovarik and Adams, 1955):

Specific activity of $\mathrm{U}^{238}=739.9 \mathrm{dis} / \mathrm{min} / \mathrm{mg} \mathrm{U}^{238}$.

Activity of $U^{238}$ in $U$ of normal isotope abundance $=(739.9 \mathrm{dis} / \mathrm{min} / \mathrm{mg})(0.99285)$

$$
=734.6 \mathrm{c} / \mathrm{min} / \mathrm{mg} \mathrm{U} \text {. }
$$

Activity of $U^{235}=(734.6 \mathrm{c} / \mathrm{min} / \mathrm{mg} \mathrm{U})(0.046)=33.8 \mathrm{dis} / \mathrm{min} / \mathrm{mg} U_{p}$

2. Specific activity of $\mathrm{Ra}^{226}$ and equivalent amounts of each decay product:

$\mathrm{N} \lambda=\frac{\left(6.0250 \times 10^{23} \text { atoms }\right)}{(226.1 \mathrm{~g})}\left(10^{-9} \mathrm{~g}\right)\left(8.1252 \times 10^{-10} / \mathrm{min}^{-1}\right)$

$=2165 \mathrm{dis} / \mathrm{min} / 10^{-9} \mathrm{~g} \mathrm{Ra} 226$.

$$
\frac{739.9 \mathrm{dis} / \mathrm{min} / \mathrm{mg} \mathrm{U}}{2165 \mathrm{dis} / \mathrm{min} / 10^{-9} \mathrm{~g} \mathrm{Ra}}=0.3417 \times 10^{-9} \mathrm{~g} \mathrm{Ra}^{226} / \mathrm{mg} \mathrm{U^{238 }}
$$

Amount of $\mathrm{Ra} 226$ in $U$ of normal isotope abundance $=\frac{734.6 \mathrm{dis} / \mathrm{min} / \mathrm{mg} \mathrm{U}}{2165 \mathrm{dis} / \mathrm{min} / 10^{-\theta} \mathrm{g} \mathrm{Ra} \mathrm{Ra}^{226}}$

$$
=0.3393 \times 10^{-9} \mathrm{~g} \mathrm{Ra}^{226} / \mathrm{mg} \mathrm{U} \text {. }
$$

3. Specific activity of $T^{232}$ and equivalent amounts of each decay product: $\mathrm{N} \lambda=\frac{\left(6.0250 \times 10^{23} \text { atoms }\right)}{(232.1 \mathrm{~g})}\left(10^{-3} \mathrm{~g} \mathrm{Th}^{232}\right)\left(9.481 \times 10^{-17} / \mathrm{min}^{-1}\right)$

$=246.1 \mathrm{dis} / \mathrm{min} / \mathrm{mg} \operatorname{Th}^{232}$.

4. Function of $\mathrm{Th}^{227}$ : (Values used for the symbols in the equations are taken from Kirby, 1954, tables 15, 18, 20, 21).

Total alpha activity/initial alpha activity

$$
\begin{aligned}
& =\frac{\alpha_{\mathrm{Pa} 231}}{\mathrm{~N}_{\mathrm{Pa} 231} \lambda_{\mathrm{Pa} 231}}+0,988 \frac{\alpha_{\mathrm{t}}}{\mathrm{N}_{0} \lambda_{\mathrm{Th} 227}}+\frac{\alpha_{\mathrm{t}}}{\mathrm{N}_{0} \lambda_{\mathrm{Ac}} 227}+\epsilon^{-\lambda_{\mathrm{Pb} 211}} \text {. } \\
& =1.0+0.988 \frac{\alpha_{t}}{\mathrm{~N}_{0} \lambda_{T_{\mathrm{Th}} 227}}+\frac{\alpha_{t}}{\bar{N}_{0} \lambda_{\mathrm{Ac}} 227}+\epsilon^{-\lambda_{\mathrm{Pb}^{211}} t} \text {. }
\end{aligned}
$$

5. Function of $\mathrm{Ra}^{226}$; (Kirby, 1954, tables 12, 21 ). Total alpha activity/initial alpha activity $=\frac{\alpha_{t}}{N_{0} \lambda_{R^{226}}}$. 


\section{Function of $\mathrm{Ra}^{223}$ :}

Total alpha activity/initial alpha activity $=3 \epsilon^{-\lambda_{\mathrm{Ra}} 223}+\left(1-\epsilon^{-\lambda_{\mathrm{Pb} 211} t}\right) \epsilon^{-\lambda_{\mathrm{Ra}}{ }^{223 t}}$.

7. Function of Ra $224:$ (Kirby, 1954, table 7).

Total alpha activity/initial alpha activity $=\frac{\alpha_{t}}{\mathbb{N}_{0} \lambda_{R a^{224}}{ }^{8}}$

8. $\mathrm{Ra}^{226}$ activity from radon train analysis:

$\mathrm{Ra}^{226}(\mathrm{dis} / \mathrm{min})=\left(2165 \mathrm{dis} / \mathrm{min} / 10^{-9} \mathrm{~g} \mathrm{Ra}^{226}\right)\left(\mathrm{g}\right.$ of $\left.\mathrm{Ra}^{226} \times 10^{-9}\right)$.

Detection efficiency $=\frac{\mathrm{Ra}^{226} \text { activity by scintillation measurement }}{\mathrm{Ra}^{226} \text { activity by radon train measurement }}$.

9. Efficiency and standard counting rate of $\mathrm{Th}^{230}, \mathrm{~Pa}^{231}, \mathrm{Ra}^{226}, \mathrm{Ra} 223$, and $\mathrm{Pb}^{210}$ determinations:

Efficiency $=\frac{\text { (activity of nuclide in carrier precipitate/detection efficiency)(100 }}{\text { (activity of nuclide in ZnS source/detection efficiency) }}$

$$
\text { S.C.R. } \begin{aligned}
\left.\mathrm{Th}^{230}, \mathrm{Ra}^{226}, \mathrm{~Pb}^{210}\right) & =\text { (efficiency) }(734.6 \mathrm{dis} / \mathrm{min} / \mathrm{mg} \mathrm{U}) \\
& =\text { dis } / \mathrm{min} / 100 \mathrm{mg} \text { of } 1 \% \text { equivalent. }
\end{aligned}
$$

$$
\text { S.C.R.(Pa } \begin{aligned}
\left.231, \mathrm{Ra}^{223}\right) & =(\text { efficiency })(33.8 \mathrm{dis} / \mathrm{min} / \mathrm{mg} \mathrm{U}) \\
& =\text { dis } / \mathrm{min} / 100 \mathrm{mg} \text { of } 1 \% \text { equivalent. }
\end{aligned}
$$

10. Efficiency and standard counting rate of $\mathrm{Rn}^{222}$ determination: Efficiencs $=\frac{\text { (activity of } \mathrm{Po}^{214} \text { in } \mathrm{Bi}_{2} \mathrm{~S}_{3} \text { precipitate)(detection efficiency) (100\%) }}{\text { (activity of } \mathrm{Ra}^{226}, \mathrm{Rn}^{222}, \mathrm{Po}^{218}, \mathrm{Po}^{214} \text {-activity of } \mathrm{Ra}^{226} \text { ) in } \mathrm{ZnS} \text { source }} x$

$$
\frac{\text { activity of } \mathrm{Rn}^{222}, \mathrm{PO}^{218}, \mathrm{PO}^{214}}{\text { activity of } \mathrm{Rn}^{222}}
$$

S.C.R. = (efficiency) $(734.6 \mathrm{c} / \mathrm{min} / \mathrm{mg} \mathrm{U})=\mathrm{c} / \mathrm{min} / 100 \mathrm{mg}$ of $1 \%$ equivalent.

11. Efficiency and standard counting rates of $\mathrm{Th}^{232}$ determination:

Efficiency $\left(\mathrm{Bi}^{212}, \mathrm{PO}^{212}\right)=\frac{\text { (activity of } \mathrm{Bi}^{212}, \mathrm{PO}^{212} \text { in } \mathrm{Bi}_{2} \mathrm{~S}_{3} \text { precipitate) }}{\text { (activity of } \mathrm{Bi}^{212}, \mathrm{PO}^{212} \text { in } \mathrm{ZnS} \text { source) }}$ Efficiency ( $\mathrm{Ra}^{224}$ )

$=\frac{\text { (peak activity of } \mathrm{Ra}^{224}, \mathrm{Rn}^{220}, \mathrm{Po}^{216}, \mathrm{Bi}^{212}, \mathrm{Po}^{212} \text { in } \mathrm{BaSO}_{4} \text { precipitate) }}{\text { (activity of } \mathrm{Bi}^{212}, \mathrm{Po}^{212} \text { in } \mathrm{ZnS} \text { source) }\left(1-\epsilon^{-7.934} \times 10^{-3} \mathrm{t} \text { ) }\right.}$

S.C.R. = (efficiency) $\left(216.4 \mathrm{c} / \mathrm{min} / \mathrm{mg}\right.$ equivalent $\left.\mathrm{Bi}^{212}\right)=\mathrm{c} / \mathrm{min} / 100 \mathrm{mg}$ of $1 \% \mathrm{Th}^{232}$. 


\section{DISCUSSION}

In many geochemical problems it is desirable to have a quantitative measure of the amount of disequilibrium in a radioactive ore or rock. In any radioactive age method using lead isotopes it is necessary to know the state of equilibrium of a given sample. The $\mathrm{Pb}^{210}$ content in the sample is especially important in order to obtain a measure of the radon loss extending back over an interval of several years. The comparison of the $\mathrm{Pb}^{210}$, the $\mathrm{Rn}^{222}$, and the $\mathrm{Ra}^{226}$ contents is of primary importance in the evaluation of the validity of an age determination by the $\mathrm{Pb}^{210}$ method (Houtermans, 1951; Kulp and others, 1953). The $\mathrm{Pb}^{210}$ to $\mathrm{Ra}^{226}$ ratio in a recently collected unweathered specimen can be used to determine the emanating power of the specimen in its natural environment. The comparison of the $\mathrm{U}^{238}, \mathrm{Th}^{230}, \mathrm{~Pa}^{231}$, and $\mathrm{Ra}^{226}$ contents may be very useful to the geologist attempting to determine the processes of weathering or alteration in the sample. Comparison of the ratios of the isotopes of radium or thorium may be helpful in the interpretation of geologic processes.

The possibility of developing a method of determining the ages of recent uranium deposits exists where the $\mathrm{Pa} 231 / \mathrm{U}$ and $\mathrm{Th} 230 / \mathrm{U}$ ratios are in good agreement and there is no indication of $\mathrm{Ra}^{226}$ or excessive $\mathrm{Rn}^{222}$ leaching. Ages ranging up to approximately 200,000 years could be determined where this method is applicable (Rankama, 1954).

Rapid methods for determining the $\mathrm{Rn}^{222}, \mathrm{Rn}^{220}$, and $\mathrm{PO}^{210}$ contents in clean water samples with very good sensitivity could be performed simply by adsorption of the polonium and bismuth isotopes on phosphorescent zinc sulfide powder in the same manner as in the determination of the efficiency of the $\mathrm{Pb}^{210}$ and thorium analyses. 


\section{ACKNOWIEDGMENTS}

This research was conducted by the U. S. Geological Survey on behalf of the Division of Raw Materials of the U. S. Atomic Energy Commission. The author is indebted to F. E. Senftle and F. J. Flanagan of the Geological Survey, for constructive suggestions and for supplying the 48-year-old thorium nitrate reagent.

\section{REFERENCES}

Carney, R. J., and Campbell, E. D., 1914, A new method for the determination of thorium in monazite sand: Am. Chem. Soc. Jour., v. 36, p. 1136.

Curtiss, L. F., and Davis, F. J., 1943, A counting method for the determination of small amounts of radium or of radon: Natl. Bur. Standards Jour. Research (Research Paper RP1557), v. 31, p. 181-195.

Dalton, S. D., Golden, J., Martin, G. R., Mercer, E. R., and Thomson, S. J., 1953, Recent studies on iron meteorites III. Determination of uranium and thorium contents: Geochimica et Cosmochimica Acta, v. 3, p. 279.

Doerner, H. A., and Hoskins, W. J., 1925, Co-precipitation of radium and barium sulfates: Am. Chem. Sac, Jour., v. 47, p. 662-675.

Flanagan, F. J., and Senftle, F. E., 1954, Tables for evaluating Bateman equation coefficients for radioactivity calculations: Anal. Chemistry, v. 26, p. 1595-1601.

Houtermans, $F_{\bullet} G_{n}$, 1951, Über ein neues Verfahren zur Durchführung chemischer Altersbestimmungen nach der Blei-methode (A new procedure for chemical age determinations by the lead method): Akad. Wiss. Heidelberg, Math.naturwiss. Kl, , Sitzungsber., Abt. II, p. 123-126.

Kirby, H. W., 1954, Decay and growth tables for the naturally occurring radioactive series: Anal, Chemistry, v. 26, p. 1063-1071.

Kovarik, A. F., and Adams, N. I., Jr., 1955, Redetermination of the disintegration constant of U $\mathrm{U}^{238}$ : Phys. Rev., v. 98, p. 46.

Kulp, J. L., Broecker, W. S., and Eckelmann, W. R., 1953, Age determination of uranium minerals by the $\mathrm{Pb}^{210}$ method: Nucleonics, v. 11 , no. 8, $\mathrm{p}, 19-21$.

Rankama, K., 1954, Isotope geology, New York, McGraw-Hill Book Co., p. 408.

Rosholt, J. N., Jr., 1954, Quantitative radiochemical method for determination of major sources of natural radioactivity in ores and minerals: Anal. Chemistry, v. 26, p. 1307-1311. 